\title{
Development of Character-Based Thematic Student Worksheets
}

\author{
Nur Wahyuni \\ College Student in Postgraduate \\ Universitas Negeri Medan \\ Medan, Indonesia \\ nurwahyuni160691@yahoo.com
}

\author{
Wisman Hadi \\ Lecture of Postgraduate \\ Universitas Negeri Medan \\ Medan, Indonesia
}

\author{
Abdurrahman Adisahputra \\ Lecture of Postgraduate \\ Universitas Negeri Medan \\ Medan, Indonesia
}

\begin{abstract}
This study aims to: (1) produce character-based student worksheets that are suitable to be used for thematic learning in the sub-themes of singing and dancing for grade 1 elementary school; (2) knowing the large increase in students interest in learning by applying the participants worksheets in the class; and (3) knowing the increase in student learning outcomes through character-based student worksheets. This student worksheet is compiled using the 4D model of Research \& Development. Data retrieval research was conducted at SDN 10187 Tanjung Morawa. The research phase is define, design, develop, and disseminate. The level of feasibility of student worksheets is obtained from expert validator and practitioner validator analyzed. After being validated and revised, the product is tested on a limited basis on students. The results of limited trials were then analyzed to determine the feasibility of student worksheets from the students point of view. Extensive tests are conducted after making improvements from the results of limited trials. The final results of the extensive test in the form of pretest and post test values were then analyzed and obtained standard gain values 0.85 with the high category.
\end{abstract}

Keywords-(Development, Worksheets, Thematics, Characters)

\section{INTRODUCTION}

The 2013 curriculum requires students to have the ability to live as individuals and citizens who are faithful, productive, creative, innovative and able to contribute to the life of society, nation, state and world civilization [1] . Learning at the age of elementary school children (SD) is a concrete operational learning phase, where the student's learning process should interact with objects or events in real terms. This is in accordance with Piaget's learning theory [8] which says that children aged 7-11 years can reason logically about concrete events and be able to apply objects into different groups. For this reason, especially in thematic learning in elementary schools where learning emphasizes direct giving to develop competencies that children have to be able to explore and understand the surrounding environment through Learning by doing. A good educator should be able to develop his ability to manage learning according to the curriculum. Output from learning activities can be seen from various aspects of cognitive, affective and psychomotor and reflected in satisfying learning achievement.

But the fact is that expectations do not match reality, education that generally occurs in society is education that is unequal between intellectual growth and development with the morality of students who are not balanced. Teachers and students only use teaching material that is ready to use as a reference, namely a textbook. In fact, textbooks facilitated by schools are very limited. Every week students must take turns carrying books or one textbook for two students. The textbook has not facilitated students to achieve the expected competence because it is not in accordance with the needs and characteristics of students at SD Negeri 181877 Tanjung Morawa. Student questions or worksheets are still very limited, so students do not practice much. More writing from the blackboard. While grade 1 students still really need a picture book and have exercises to make students think and practice a lot so that students can read fluently and count faster with great fun. This has an impact on students' interest in learning who tends to feel bored in participating in learning. Likewise, counting questions use long sentences without colored pictures that can stimulate student interest. Teaching materials such as student worksheets (LKPD) for grade 1 elementary school students are not used, or from printing to school there is no giving or facilitating character-based LKPD for grade 1 students. All questions are only based on textbooks or from teachers who are teaching in class is then written on the board so that all students can see and copy it to work. This limitation makes students' values and interests of learning not optimal.

Teaching materials are not in accordance with the characteristics of students who currently have very little character of honesty and caring. The learning system forces students to follow the learning process in sequence and time, while each student sounds different in terms of understanding the material. Low-ability students will find learning like this very boring. In accordance with its characteristics, a learning system with thematic teaching materials in the form of LKPD provides an opportunity for students to develop based on their individual abilities. LKPD that is needed by students is LKPD that is interesting and can invite students to be more creative in their learning. Based on the problems and given the importance of thematic learning in elementary schools, research to develop LKPD in thematic learning is very necessary. In this case the researcher seeks to develop thematic learning tools because of the limitations of characterbased thematic teaching materials in SDN 101877 Tanjung Morawa. 


\section{THEORETICAL}

Teaching materials are all forms of materials used to help the teacher / instructor in carrying out teaching and learning activities. The material in question can be either written material or unwritten material. Teaching materials enable students to learn a basic competency or competency in a coherent and systematic manner so that they are able to master all competencies fully and integrated [4]. Teaching material is a set of learning tools or tools that contain learning materials, methods, boundaries and ways to evaluate systematically and attractively designed in order to achieve the expected goals, namely achieving competence or subcompetence with all its complexity [13]. In addition, according to Prastowo [7] said that teaching material is a set of material that is arranged systematically, both written and unwritten so as to create an environment or atmosphere that allows students to learn. From some views on the understanding of teaching materials, it can be understood that teaching materials are all materials (both information, tools, and texts) that are arranged systematically, which displays a complete figure of competencies that will be mastered by students and used in the process of learning activities with learning objectives and study the implementation of learning. Teaching material is a guide for teachers to direct all activities in the learning process and is an evaluation tool for achieving or mastering learning outcomes.

There are many functions and objectives of teaching materials according to Prastowo [7] the preparation of teaching materials, namely: (1) Providing teaching materials in accordance with curriculum demands by considering the needs of students, namely teaching materials that are in accordance with the characteristics and setting or social environment of students; (2) Assist students in obtaining alternative teaching materials in addition to text books that are sometimes difficult to obtain; (3) Facilitating the teacher in carrying out learning. Teaching materials by their nature consist of technology-based teaching materials, teaching materials needed for human interaction. Forms of teaching materials can be grouped into four, as written below: (1) Printed teaching materials, printed teaching materials are a number of materials used in paper, which are used in the teaching and learning process. One of the reasons why printed teaching materials are still the main media in teaching material packages in schools, because until now print teaching materials are still the easiest media to obtain and are more standard than computer programs. The advantage is that written material usually displays a table of contents, making it easier for teachers to show students which parts are being studied, the costs for procurement are relatively inexpensive, easy to use, relatively light and can be read anywhere, can motivate readers to carry out activities such as note taking, sketching and marking; (2) Handouts, are written materials prepared by a teacher to enrich the knowledge of students. The handout is taken from several literatures that are in accordance with the material to be taught and the basic competencies contained in the syllabus; (3) Non-printed teaching materials, excess types of non-printed teaching materials, OHT (Overhead Transparentcies), the use of projectors that can be operated can be controlled directly by the instructor, requiring only a little preparation, especially useful for large classes. The drawback is, it requires special equipment to operate it, the project is too big when compared to other projectors; (4) Audio, the advantages of audio media that is easily prepared using ordinary tape, can be applied in almost all subjects; and flexible and easily adapted, either alone or related to other materials [7].

Mulyasa [5] integrated thematic learning is learning that is applied at the level of basic education which presents a learning process based on themes and then combined with other subjects. Thematic learning as a learning model is one type of integrated learning model. The term thematic learning model is basically an integrated learning model that uses themes to link several subjects so as to provide meaningful experiences to students [2]. Subroto [10] asserts that integrated learning is learning that begins with a specific subject or theme that is associated with another subject, certain concepts are linked to other concepts, which are carried out spontaneously or planned, both in one or more fields of study, and with a variety of student learning experiences, learning becomes more meaningful. According to Trianto [13] thematic learning also has an important meaning in teaching and learning activities. There are several underlying reasons, including: (1) The child's world is the real world, the child's level of mental development always starts with the real thinking stage; (2) The process of children's understanding of a concept in an event / object is more organized, the process of children's understanding of a concept in an object is very dependent on prior knowledge; (3) Learning will be more meaningful, learning will be more meaningful if learning that students have learned can utilize to learn the next material; (4) Give students opportunities to develop their abilities, integrated learning provides opportunities

Lickona [3] argues that a person is said to be of good character if in real life he has three habits, namely knowing good things (habits of mind) wanting good things (habits of heart), and doing good things (habits of action). Based on the description can be obtained by understanding that character is a person's self-image in the form of attitudes, actions, and behaviors that can be seen from their habits. Character education can be interpreted as value education, character education, moral education, character education, which aims to provide good and bad decisions, maintain what is good, and realize goodness in everyday life with all my heart. Wiyani [14] argues that character education is the process of giving guidance to students to become fully human beings, who have character in the dimensions of heart, mind, body, and taste and intention. In line with the opinions above Zubaedi [16] argues that character education is a genuine effort to understand, shape, foster, ethical values, both for oneself and for all society or citizens as a whole.

Koesuma [15] stated the objectives of character education as follows: (1) strengthen and develop values that are considered important and necessary so that it becomes a unique student ownership personality as the values are developed; (2) correcting student behavior that is not 
compatible with the values developed by the school; and (3) building harmonious connections with families and communities in playing the role of shared character. According to Muslich [6] the goal of character education is to improve the quality of the implementation and results of education that lead to the achievement of the formation of the character and noble character of students as a whole, integrated, and balanced. Furthermore, in The Six Pillars of Character issued by the Character Counts Coalition (a Project of the Joseph Institute of Ethics [15], the six pillars of character education are described as follows: (1) Trrustworthiness, the form of character that makes someone becomes integrity, honest, and loyal, (2) fairness, a form of character that makes someone have an open mind and does not like to take advantage of others, (3) caring, a form of character that makes a person have a caring attitude and concern for others and social conditions the environment, (4) respect, the form of character that makes one always respect and respect others, (5) citizenship, the form of character that makes a person aware of laws and regulations and care for the natural environment, and (6) responbility, the form of character that makes someone responsible, disciplined, and always do something as possible. In accordance with the function of national education [2] character education is intended to develop capabilities and shape the character and civilization of a dignified nation in order to educate the nation's life. More specifically, character education has three main functions, namely: (1) Formation and development of potential, character education functions to shape and develop the potential of Indonesian people or citizens so that they think well, have good hearts, and behave in accordance with the philosophy of life of Pancasila; (2) Improvement and strengthening, character education functions to improve the negative character of humans and citizens of Indonesia and strengthen the role of family, education units, society, and government.

According to Siddiq [9] states that LKPD is packaged with only an emphasis on training, assignments or questions only. Although it only emphasizes this matter, LKPD still presents a description of the material but is presented briefly. The questions presented in LKPD must really be developed based on an analysis of learning objectives / competencies that have been translated into achievement indicators. According to the Ministry of National Education [2]. Student Worksheets (LKPD) are sheets containing assignments that must be done by students. Activity sheet in the form of instructions or steps to complete a task. The task must be clear the basic competencies to be achieved. Trianto [13] argues that LKPD is a student guide that is used to carry out investigation or problem solving activities. This activity sheet can be a guide for developing cognitive aspects of the exercise and a guide for developing aspects of learning in the form of experiments or demonstrations. LKPD contains a set of fundamental activities that must be done by students to maximize understanding in an effort to form basic abilities in accordance with the learning indicators that must be taken. Meanwhile, according to Prastowo [7] LKPD is not an abbreviation of Student Activity Sheet but a Student Worksheet, which is teaching material that has been packaged in such a way, so that students are expected to be able to study the teaching material independently. According to Toman [12] states that LKPD is a teaching material that is prepared to support individual activities that will be done while learning and will also allow students to have an interest in learning by themselves given the steps associated with these activities.

Considering the importance of LKPD for learning activities we cannot be separated from the assessment of the functions, goals, and benefits of LKPD. The following explanation of the study Prastowo [7]. LKPD functions: (a) as teaching material that can minimize the role of educators, but more activating students; (b) as teaching materials that make it easier for students to understand the material presented; (c) as a concise and rich teaching material for training; and (d) facilitate the implementation of teaching to students. There are five types of LKPD, namely: (a) LKPD that helps students find a concept. In accordance with the principle of constructivism, a person will learn to construct knowledge in his own brain. This type of LKPD includes what students must do, including doing, observing, and analyzing. The first time to make LKPD we need to formulate steps that must be done by students and then they have to observe the phenomenon of the results of activities. Furthermore, students are given analysis questions to be associated with the concepts they are learning. (b) LKPD which helps students to apply and integrate various concepts that have been discovered. LKPD this type of students are trained to apply concepts that have been learned in everyday life. This LKPD conducts discussions to train students to be responsible and respectful of others. (c) LKPD which functions as a guide to LKPD learning contains questions or answers whose answers are in books and students are required to read books to find the answers. LKPD is suitable for remediation and helps students memorize and understand learning material. (d) LKPD which functions as a strengthening of LKPD is more directed to the deepening and application of LKPD learning materials suitable for enrichment. e) LKPD which functions as a guideline for this LKPD, the practice manual is one of the contents of LKPD.

According to the Ministry of National Education in [7] the steps in the preparation of LKPD are as follows: (1) Conducting curriculum analysis, before making LKPD the first step is to analyze the curriculum, curriculum analysis is intended to determine the material to be made LKPD teaching materials. This analysis is done by looking at the subject matter, learning experience, and the material to be taught. Next pay attention to the competencies that must be possessed by students; (2) Prepare LKPD needs maps, LKPD maps are very necessary to know the number of LKPDs that must be written and see the sequence or sequence of LKPD. This sequence is needed in determining the priority of writing; (3) Determine LKPD titles, LKPD titles are determined on the basis of basic competencies, subject matter, learning experiences contained in the curriculum. A basic competency can be used as a title if the scope of the competency is not too large. If the basic competency is too large and can be broken 
down into a number of basic material (MP) to get a maximum of 4 subjects, but if more than $4 \mathrm{MP}$, then it must be rethought whether the basic competency needs to be broken down, then made into several LKPD titles. (4) Writing LKPD.

\section{METHOD OF RESEARCH}

This research is an educational development research $(\mathrm{R} \&$ D). This study aims to develop a Problem Based Learning Worksheet based on Class 1 of SDN 101877 Tanjung Morawa. Subjects in the study were 60 students in class 1, from $1 \mathrm{~A}$ as eksperiment class, 1B as eksperiment class and 1c as control class. The device development model as suggested by Thiagarajan, [13] is a 4-D model, which consists of 4 stages of development namely, defining, designing, developing and disseminating. The trial design in this study used the One Group Pretest-Posttest Design design. The first step is to take measurements as an initial test (pretest), then subject to treatment within a certain period, then a final trial (posttest). The pretest and posttest design research design is with the following table pattern:

TABLE 1 DESIGN OF ANALYSIS

\begin{tabular}{ccc}
\hline Pretest & Treatment & Postest \\
\hline $\mathbf{T}_{\mathbf{1}}$ & $\mathrm{X}$ & $\mathrm{T}_{2}$ \\
\hline
\end{tabular}

Description:

$\mathrm{TI}=$ Test before treatment

$\mathrm{T} 2=$ Test after treatment

$\mathrm{X}=$ Treatment

The following data collection instruments will be used in this study; (1) questionnaire; and (2) test. Analysis of the results of expert validation using the formula:

Description:

$$
\mathrm{X}=\frac{\sum x}{\pi}
$$

$$
\begin{array}{ll}
\overline{\mathrm{X}} & =\text { mean } \\
\Sigma x & =\text { total score } \\
n & =\text { Many question. }
\end{array}
$$

Data analysis of student effectiveness is done by analyzing student learning completeness, achievement indicators, student responses and learning representations.

\section{RESULTS AND DISCUSSION}

Data validation results by expert lecturers on content material content / material eligibility, language eligibility and graphic worthiness. Validation from expert lecturers is done twice, the first is done by giving every aspect, while the

\begin{tabular}{|c|c|c|c|c|c|}
\hline $\begin{array}{c}\text { Stape } \\
\text { Valida } \\
\text { tion }\end{array}$ & $\underset{\text { er }}{\text { Numb }}$ & Assesment Aspect & Mean & $\%$ & $\begin{array}{l}\text { Catego } \\
\text { ry }\end{array}$ \\
\hline \multirow{3}{*}{1} & 1. & $\begin{array}{l}\text { Content / material } \\
\text { eligibility }\end{array}$ & 3,67 & $\begin{array}{c}73,4 \\
0\end{array}$ & good \\
\hline & 2. & Language Egibility & 3,80 & $\begin{array}{c}76,0 \\
0\end{array}$ & good \\
\hline & 3. & Design Egibility & 3,59 & $\begin{array}{c}89,7 \\
5\end{array}$ & good \\
\hline \multicolumn{3}{|c|}{ Mean } & 3,68 & $\begin{array}{c}79,7 \\
1\end{array}$ & Good \\
\hline \multirow{3}{*}{2} & 1. & $\begin{array}{l}\text { Content / material } \\
\text { eligibility }\end{array}$ & 4,50 & $\begin{array}{c}90,0 \\
0\end{array}$ & Best \\
\hline & 2. & Language Egibility & 4,50 & $\begin{array}{c}90,0 \\
0\end{array}$ & Best \\
\hline & 3. & Design Egibility & 3,94 & $\begin{array}{c}98,5 \\
0\end{array}$ & Good \\
\hline \multicolumn{3}{|c|}{ Score Mean } & 4,31 & $\begin{array}{c}92,8 \\
3\end{array}$ & Best \\
\hline
\end{tabular}
second can only be seen on all products after revision. Following are the validation results in each aspect.
TABLE 2 VALIDITION EXPERT CONTENT CONTENT PHASE I AND 2

In this table, it can be seen a significant increase between stage 1 validation and stage 2 validation. The average score at stage 1 is 3.68 with the category of "good" and the average score at stage 2 is 4.31 with the category "very well". The following is a graph of the results of the validation of the material and graphic experts.

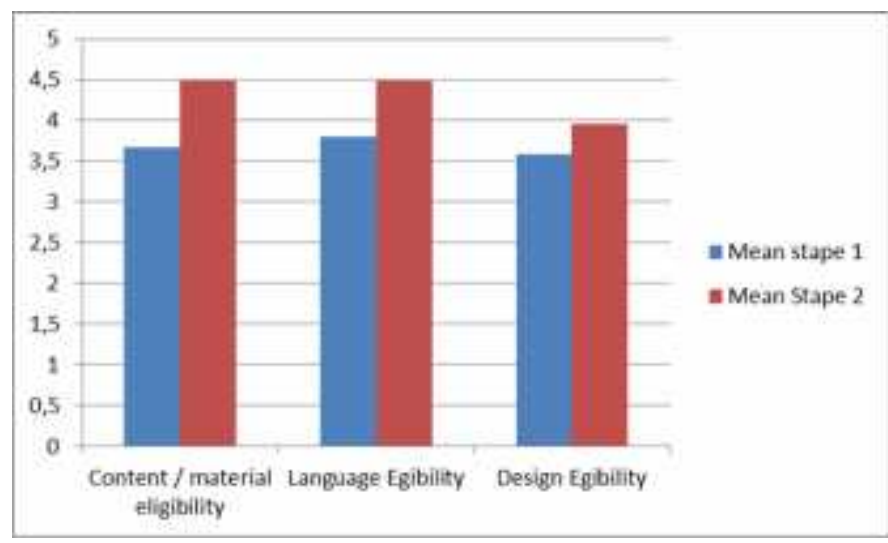

Fig. 1. Validation Diagram of Expert Content / Material Phase 1 and Phase 2

Furthermore, the tests provided in this student worksheet are conducted to see further what character values are embedded in students through student worksheets. For average test results, can be seen in Table 3:

TABLE 3. MEAN OF PRETES AND POSTEST

\begin{tabular}{|c|c|c|}
\hline Class & $\begin{array}{c}\text { Mean } \\
\text { Pretes }\end{array}$ & Mean Postes \\
\hline 1A & $\mathbf{4 0 , 5 0}$ & $\mathbf{8 8 , 0 0}$ \\
1B & $\mathbf{5 0 , 0 0}$ & $\mathbf{8 5 , 0 0}$ \\
1C & 45,25 & $\mathbf{8 3 , 5 0}$ \\
\hline
\end{tabular}




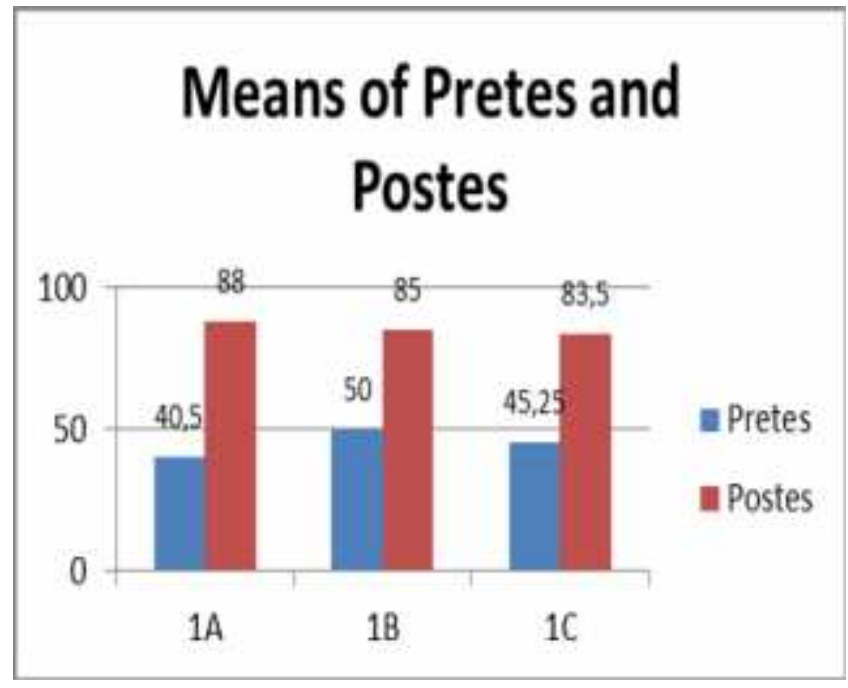

Fig. 2. Means of Pretest and Postest

This means that the character values of students through the use of character-based student worksheets are much better, because in the learning process with this model students are directed to carry out a number of activities related to daily life and in the process of instilling character values in them. Teachers who act as facilitators in learning make students learn independently so that they can foster student activities to explore the deeper knowledge they have and instill independent and responsible character. In addition, the development of LKPD trains students to find their own concepts based on real life problems and activities with inquiry skills (science process skills) to form better and longer lasting concepts of student knowledge.

\section{CONCLUSIONS}

From the results of this study it can be stated that the development of character-based thematic worksheets influences student learning outcomes. This can be seen from the results of the average pretest score of students who only 40.50 in class $1 \mathrm{~A}$ to 88.00 and in class $1 \mathrm{~B}$ an average of 50.00 to 88.00 and $1 \mathrm{C}$ grade an average of 45.25 to 83,50 and with a gain value of 0.85 with a high category.

\section{REFERENCES}

[1] Departemen Pendidikan Nasional. 2010. Pendidikan Karakter Pada Anak Usia Dini dan Madrasah. Jakarta: Balitbang Puskur Depdiknas

[2] Kemendikud. 2010. Kementerian Pendidikan Nasional Direktorat Jenderal Manajemen Pendidikan Dasar Dan Menengah Direktorat Pembinaan Sekolah Menengah Atas. Jakarta : DEPDIKNAS

[3] Lickona, Thomas. 1991. Educating for Character How Our School Can Teach Respect and Responsibility. New York: Bantam Books.

[4] Majid, A. 2008. Pengembangan Bahan Ajar Untuk Meningkatkan Kompetensi Dasar. Jurna Tabularasa. 3 (1) : 54-63.

[5] Mulyasa. 2013. Pembelajaran Tematik Berbasis Karakter. Jakarta: Media Pustaka.

[6] Muslich \& Mansur. 2007. KTSP: Dasar Pemahaman dan Pengembangan. Jakarta: Bumi Aksara.

[7] Prastowo, A . 2012. Panduan Kreatif Membuat Bahan Ajar Inovatif. Yogyakarta: DIVA Press.

[8] Santrock. 2013. Teori Pembelajaran. Jakarta: Grafindo Media.

[9] Siddiq, M. 2008. Pengembangan LKPD Tematik Terpadau Untuk Meningkatkan Kemampuan Pemecahan Masalah Pada Siswa Kelas VII SMPN Sidoarjo. Jurnal UNSA. 5 (5) : 125-145.

[10] Subroto. Tisno \& Ida 2000. Pembelajaran Terpadu. Jakarta: Pusat Penerbitan Universitas Terbuka.

[11] Sugiyono. 2008. Metode Penelitian Pendidikan (Pendekatan Kuantitatif, Kualitatif, dan R\&D). Bandung: Alfabeta.

[12] Toman, K. 2013. Desain Pembelajaran Berbasis Karakter. Makassar : Gramedia Kencana.

[13] Trianto. 2011. Mendesain Model Pembelajaran Inovatif-Progresif. Jakarta: Kencana.

[14] Widodo \& Jasmadi. 2008. Evaluasi dan Desain Pembelajaran. Jakarta : Media Pustaka.

[15] Wiyani, S. 2013. Pendidikan Berbasis Karakter. Bandung: Kencana Pustaka.

[16] Zubaedi, M. 2012. Analisis Pembelajaran Berbasis Karakter Untuk Meningkatkan Hasil Belajar Siswa Kelas VII SMPN Cileunyi. 7 (5) : 19-25. 